\title{
DESAIN TRIANGULASI KONKUREN DALAM MENGANALISIS MODEL 3I MARKETING 3.0 SEBAGAI ENTREPRENEURIAL MARKETING USAHA MENENGAH KECIL MENENGAH MENGHADAPI MASYARAKAT EKONOMI ASEAN
}

\author{
Metta Padmalia \\ Fakultas Manajemen dan Bisnis, Universitas Ciputra Surabaya \\ metta.padmalia@ciputra.ac.id \\ Dewi M. Immanuel \\ Fakultas Manajemen dan Bisnis, Universitas Ciputra Surabaya
}

\begin{abstract}
Entrepreneurial Marketing is a marketing activity by small and medium enterprises (SMEs) that uses an entrepreneurial approach. Currently, government still pays less attention to the implementation of SMEs' entrepreneurial marketing. Yet, as the backbone of Indonesian economy, SMEs can play an important role when ASEAN Economic Community (AEC) begins to implement. With respect to these issues, we aim to identify the government's role in advocating SMEs' interests, especially in the Marketing 3.0. era. In the Marketing 3.0. era, marketing is translated into brand triangle through $3 i$ Model. We use a mixed method with a concurrent triangulation design. The first part of this study interviewed five SME owners who receive assistance from Diskoperindag of Magelang City regarding the following issues: implementation of $3 i$ Model, the role of Diskoperindag in assisting businesses, and their understanding of MEA. Basically, this part explore the conditions of SMEs concerning the issues being questioned. Meanwhile, the second part is a quantitative analysis that involve 40 customers who bought SMEs who receive assistance from Diskoperindag. Using multiple regression analysis, we find that only brand and brand identity parts of $3 i$ Model have significantly positive effect on decisions to buy SMEs' products.
\end{abstract}

Keywords: SMEs, entrepreneurial marketing, concurrent triangulation design, Marketing 3.0, 3i Model, purchase decision.

\begin{abstract}
ABSTRAK
Entrepreneurial Marketing adalah kegiatan pemasaran oleh usaha dengan skala kecil menengah (UMKM) menggunakan pendekatan kewirausahaan. Perhatian pemerintah masih kurang optimal terhadap penerapan entrepreneurial marketing dari UMKM, padahal sebagai fondasi perekonomian negara, UMKM memegang peranan penting ketika dimulainya era Masyarakat Ekonomi ASEAN (MEA). Melihat fenomena tersebut, peneliti ingin mengidentifikasi bagaimana peran serta yang telah dilakukan oleh pemerintah dalam membina UMKM, terutama dalam era Marketing 3.0. Pada era Marketing 3.0, pemasaran diterjemahkan sebagai segitiga merek melalui Model 3 i. Penelitian yang dikembangkan adalah penelitian kombinasi dengan desain triangulasi konkuren. Bagian pertama penelitian ini melibatkan 5 orang pemilik UMKM binaan
\end{abstract}


Diskoperindag kota Magelang yang diwawancarai terkait penerapan Model 3i, peran serta Diskoperindag, dan pemahamannya terhadap MEA. Hasil dari bagian pertama berupa eksplorasi kondisi UMKM terkait aspek-aspek yang ditanyakan. Bagian kedua penelitian melibatkan 40 orang konsumen yang telah membeli produk UMKM binaan. Pengujian data kuantitatif pada bagian kedua dilakukan dengan analisis regresi linear berganda. Hasil penelitian menunjukkan bahwa pada bagian dari Model 3i hanya identitas merek dan integritas merek saja yang memiliki pengaruh positif dan signifikan terhadap keputusan pembelian produk UMKM.

Kata kunci: UMKM, entrepreneurial marketing, desain triangulasi konkuren, Marketing 3.0, Model 3i, keputusan pembelian.

\section{PENDAHULUAN}

Kesepakatan negara-negara ASEAN untuk membentuk suatu kondisi pasar baru tanpa batas di dalam bidang ekonomi disebut dengan Masyarakat Ekonomi ASEAN (MEA). MEA diadaptasi dari istilah ASEAN Economic Community (AEC) yang berlaku mulai tanggal 31 Desember 2015 (Kartajaya et al., 2015) berdampak pada aliran bebas barang dan jasa dari satu negara ke negara lain tanpa pungutan bea masuk Tyas dan Safitri (2014). Kondisi tersebut dapat menciptakan suatu tantangan sekaligus peluang baru bagi perekonomian negara Indonesia. Kartajaya et al. (2015) menyebutkan bahwa terdapat peluang bagi negara kita untuk memasarkan produk dan jasa seluas-luasnya ke negara ASEAN. Alasannya adalah Indonesia memiliki kekuatan dan potensi tinggi di ASEAN dilihat dari jumlah penduduk yang mencapai 38,61\% dari jumlah masyarakat ASEAN dan GDP yang telah mencapai 36,04\%. Lebih lanjut lagi, MEA juga menjadi tantangan bagi Indonesia karena apabila tidak siap, maka pemain lokal dengan modal terbatas dapat 'terlindas' oleh pemain-pemain asing (Kartajaya et al., 2015).

MEA dapat menjadi peluang besar untuk membangun perekonomian dalam negeri apabila Indonesia memiliki strategi yang baik. Salah satu cara untuk membangun perekonomian Indonesia adalah dengan mengembangkan sektor UMKM (Usaha Mikro Kecil dan Menengah) karena berperan besar dalam perekonomian Indonesia. UMKM memiliki peran yang sangat vital di dalam upaya pembangunan dan pertumbuhan ekonomi karena karakteristiknya: padat karya, terdapat di semua kota, tergantung pada bahan baku lokal, serta sebagai penyedia utama kebutuhan pokok masyarakat dengan pendapatan rendah (Tambunan 2012). Berdasarkan data dari BPS Online, unit UMKM di Indonesia tumbuh secara signifikan dengan jumlah 53,8 juta unit usaha pada tahun 2010, hingga mencapai 57,8 juta unit usaha pada tahun 2013; atau dapat dikatakan tumbuh sekitar 4 juta unit dalam kurun waktu 3 tahun. UMKM dapat menjadi kekuatan baru penopang perekonomian negara dalam menghadapi MEA karena jumlah unit usaha yang sedemikian besar dan tingkat pertumbuhannya yang juga tinggi. Akan tetapi, daya saing produk UMKM masih menjadi sebuah kendala terbesar dalam menghadapi MEA. 
Ganie (2012) menyebutkan bahwa salah satu perencanaan yang dilakukan pemerintah dalam menyongsong MEA adalah pemberdayaan UMKM dengan memberikan pelatihan dan pinjaman modal usaha. Kehadiran MEA berpotensi akan mengembangkan UMKM karena semakin luasnya akses terhadap pasar dan sumber pembiayaan. Akses keuangan yang semakin terbuka seharusnya disikapi oleh UMKM, yang umumnya masih bersifat tradisional, sebagai peluang untuk lebih berkembang. UMKM adalah salah satu tulang punggung perekonomian bagi negara berkembang, misalnya Indonesia (Hadiyati 2015). Oleh karena itu, dibutuhkan pembinaan UMKM yang baik oleh pemerintah, melalui pelatihan-pelatihan dan kemudahan peminjaman modal usaha (Majalah Swa Online 2014). Guna meningkatkan daya saing UMKM, pemerintah yang diwakili oleh Diskoperindag (Dinas Koperasi Perindustrian Perdagangan) di masing-masing kota melakukan kegiatan pembinaan terhadap unitunit UMKM. Kegiatan pembinaan berupa pelatihan produk dan membantu pemasaran produk melalui pameran-pameran dan kerjasama dengan unit usaha lain diluar UMKM. Setiap kegiatan pembinaan bertujuan untuk meningkatkan daya saing UMKM untuk menghadapi MEA.

Hills, Hultman, dan Miles (2008) berpendapat bahwa pemasaran UMKM harus dikembangkan secara berbeda dengan pemasaran perusahaan yang lebih besar. Istilah yang banyak digunakan untuk menyebut pemasaran bagi usaha skala kecil dan menengah adalah entrepreneurial marketing (Pandeya 2010). Konsep ini berbeda fokus dengan pemasaran tradisional yang umum digunakan. Apabila pemasaran tradisional umumnya berfokus pada perencanaan secara formal melalui uji statistik, maka entrepreneurial marketing lebih berfokus pada penggunaan intuisi bersifat informal dalam pengambilan keputusan (Pandeya 2010).

Pemasaran mengalami pergeseran konsep dari berfokus pada produk (Marketing 1.0), ke orientasi pelanggan (Marketing 2.0), dan akhirnya saat ini pemasaran harus lebih didorong oleh nilai-nilai tertentu/values-driven (Marketing 3.0) (Kartajaya et al., 2015). Era Marketing 3.0 adalah era di mana praktik pemasaran sangat dipengaruhi oleh perubahan perilaku dan sikap konsumen. Konsumen yang saling terhubung dapat memengaruhi strategi pemasaran perusahaan. Hal ini terjadi karena adanya tiga kekuatan besar berupa media sosial (twitter, facebook, wikipedia, dan sejenisnya), globalisasi, dan munculnya masyarakat kreatif (Kotler et al., 2010). Kotler et al., (2010) juga menekankan bahwa perusahaan haruslah melihat pelanggan sebagai manusia multidimensi yang terdiri dari pikiran, hati, dan spirit, sehingga diperkenalkanlah Model 3i yang merupakan harmonisasi dari identitas merek, integritas merek, dan citra merek. Model ini menjelaskan bahwa pemasaran perusahaan harus dapat mendefiniskan identitas (identity) unik dan memperkuatnya dengan integritas (integrity) yang otentik sehingga terbangunlah citra (image) yang kuat. Merek yang kuat diharapkan akan memengaruhi keputusan konsumen untuk membeli produk perusahaan. 
Berdasarkan fenomena-fenomena yang telah diuraikan, maka peneliti memandang perlu dilakukan penelitian tentang entrepreneurial strategy Marketing 3.0 terhadap UMKM binaan pemerintah dalam kesiapannya menghadapi MEA 2015. Penelitian ini menggunakan metode kombinasi (mixed methods) dengan tujuan untuk saling melengkapi gambaran hasil studi mengenai fenomena yang diteliti sehingga dapat memperkuat analisis penelitian. Subyek penelitian adalah pemilik UMKM binaan Diskoperindag Kota Magelang yang menitipkan barang dagangannya di Hotel Wisata. Pertimbangan pemilihan subyek penelitian adalah bahwa Hotel Wisata menjalin kerjasama dengan Diskoperindag Kota Magelang, sehingga UMKM yang menitipkan barang dagangan di hotel tersebut dapat dipastikan merupakan binaan Diskoperindag. Selain itu, penelitian ini juga melibatkan kontribusi dari para konsumen yang telah membeli produk UMKM tersebut. Berdasarkan situasi problematik yang telah dijabarkan, maka penelitian ini memasalahkan: (a) bagaimana pemahaman para pemilik UMKM terhadap MEA? (b) bagaimana peran serta Diskoperindag dalam mendukung perkembangan UMKM untuk menyambut MEA? (c) bagaimana entrepreneurial strategy berdasarkan model 3i Marketing 3.0 telah diterapkan oleh UMKM dalam menghadapi MEA? (d) apakah identitas merek berpengaruh positif terhadap keputusan pembelian produk?; (e) apakah integritas merek berpengaruh positif terhadap keputusan pembelian produk? (f) apakah citra merek berpengaruh positif terhadap keputusan pembelian produk?

Penelitian ini diharapkan memberikan sumbangan ilmiah, pemikiran, dan ide untuk memahami strategi entrepreneurial marketing dalam cakupan model $3 \mathrm{i}$ dari Marketing 3.0. Penelitian ini diharapkan dapat menganalisis bagian-bagian model $3 \mathrm{i}$ Marketing 3.0 yang memengaruhi keputusan pembelian produk UMKM kota Magelang.

\section{KAJIAN PUSTAKA DAN PENGEMBANGAN HIPOTESIS}

\section{Entrepreneurial Marketing}

Konsep entrepreneurial marketing digunakan untuk mendeskripsikan proses perusahaan dalam mengejar kesempatan dalam kondisi ketidakpastian pasar (Becherer, Haynes, \& Fletcher 2006). Morris, Schindehutte, dan LaForge (2002) mendefinisikan entrepreneurial marketing sebagai identifikasi proaktif dan eksploitasi peluang dalam memperoleh pelanggan melalui pendekatan yang inovatif untuk memberikan nilai tambah suatu bisnis. Menurut Ionita (2012), kemunculan konsep tersebut merupakan respon beberapa hasil penelitian yang menunjukkan ketidaksesuaian teori pemasaran tradisional dengan praktik pemasaran yang dilakukan oleh pelaku usaha mikro kecil menengah (UMKM). Kondisi tersebut menggambarkan bahwa konsep pemasaran tradisional yang semula dikembangkan untuk perusahaan besar, ternyata tidak dapat diaplikasikan langsung ke UMKM tanpa adanya penyesuaian (Stokes, 2000). 
Entrepreneurial marketing diasosiasikan dengan tindakan pemasaran yang lebih opportunity-driven bila dibandingkan dengan pemasaran tradisional (Hills, Hultman, dan Miles 2008) dan konsep ini merupakan integrasi pemasaran dengan inovasi yang berpusat pada prinsip-prinsip entrepreneurship (Morrish et al., 2010). Pebisnis dituntut untuk berinovasi dalam penerapan entrepreneurial marketing agar dapat memengaruhi keputusan pembelian konsumen secara positif untuk meningkatkan permintaan.

\section{Keputusan Pembelian}

Keputusan pembelian adalah proses yang mengkombinasikan pengetahuan untuk mengevaluasi dua atau lebih perilaku alternatif dan memilih salah satu di antaranya (Peter \& Olson 2000). Menurut Swastha dan Irawan (2008), keputusan pembelian adalah pemahaman konsumen tentang keinginan dan kebutuhan akan suatu produk dengan menilai dari sumber-sumber yang ada dengan menetapkan tujuan pembelian serta mengidentifikasi alternatif sehingga pengambil keputusan untuk membeli yang disertai dengan perilaku setelah melakukan pembelian. Keputusan pembelian merupakan tahap penilaian keputusan yang menyebabkan pembeli membentuk pilihan di antara beberapa merek yang tergabung dalam perangkat pilihan dan membentuk maksud untuk membeli (Kotler \& Armstrong 2003).

Setiadi (2003) menjabarkan proses keputusan pembelian dalam lima tahapan dngan masing-masing indikator yang dapat memengaruhi tindakan konsumen. Pertama, pengenalan masalah yaitu suatu keadaan di mana terdapat perbedaan antara keadaan yang diinginkan dengan keadaan yang sebenarnya terjadi. Indikator ini dapat diukur melalui pemenuhan kebutuhan, produk komoditas dan kualitas produk. Kedua, pencarian informasi untuk mengumpulkan alternatif dari berbagai sumber. Ketiga, evaluasi alternatif untuk mengevaluasi pilihan produk atau merek dan memilihnya sesuai dengan yang diinginkan konsumen. Keempat, pengambilan keputusan pembelian konsumen yang dapat diukur melalui seberapa besar pengaruh dari orang lain, kenginan dan kemampuan konsumen serta intensitas pembelian konsumen. Kelima, perilaku pasca pembelian di mana konsumen mengevaluasi produk yang dibelinya apakah memuaskan atau tidak, jika memuaskan dan sesuai dengan harapan konsumen maka ada kemungkinan ia akan kembali membeli produk tersebut.

\section{Marketing 3.0}

Kajian pemasaran bertransformasi dari Marketing 1.0 ke Marketing 2.0 hingga menuju ke era Marketing 3.0. Marketing 1.0 mengandalkan rational intelligence melalui produk bagus dengan harga terjangkau. Menurut Kotler et al. (2010), konsumen memilih produk berdasarkan tinggi rendahnya harga yang ditawarkan produsen. Marketing 2.0 ditandai dengan emotional marketing yang mengandalkan emotional intelligence. Tagline Marketing 2.0 adalah "sentuhlah hati pelanggan". Produk yang ditawarkan mungkin lebih mahal dibandingkan produk kompetitor, tetapi produk tetap dipilih oleh konsumen karena banyak yang sudah memiliki ikatan emosional dengan produk tersebut (Kotler et al., 2010). 
Marketing 3.0 yang sedang berkembang saat ini dilandasi oleh spiritual intelligence. Pemasaran dalam konsep ini bergeser ke arah spiritual yang diyakini tidak hanya mendongkrak profit, tetapi juga menjamin kelanggengan dan penguatan karakter merek, serta membentuk perbedaan yang benar-benar otentik sehingga sulit ditandingi. Hal penting dalam Marketing 3.0 adalah pemasar harus membidik pikiran dan spirit secara simultan untuk meraih hati konsumen. Konsep Marketing 3.0 melihat pelanggan sebagai manusia multidimensi yang terdiri dari pikiran, hati, dan spirit. Kotler et al. (2010) memperkenalkan Model $3 \mathrm{i}$ (identity, integrity, dan image), di mana dalam model ini perusahaan harus dapat mendefiniskan identitas unik dan memperkuatnya dengan integritas yang otentik untuk membangun citra yang kuat.

Menurut Kotler et al. (2010), di era Marketing 3.0, pemasaran harus didefinisikan kembali sebagai segitiga dari merek, positioning, dan diferensiasi. Merek tidak berarti apa-apa jika hanya mengartikulasikan positioningnya. Merek mungkin memiliki identitas yang jelas dalam benak konsumen, tetapi belum tentu merupakan identitas yang baik. Kotler dan Keller (2007) mengungkapkan bahwa positioning adalah pernyataan yang tegas untuk menyadarkan konsumen agar berhati-hati terhadap merek yang tidak otentik. Hubungannya dengan segitiga model $3 i$ adalah positioning tidak akan lengkap tanpa diferensiasi. Diferensiasi sering dipandang sebagai inti dari merek yang mencerminkan integritas merek yang sebenarnya, sehingga diferensiasi merupakan bukti kuat bahwa merek berhasil menyampaikan janjinya. Integritas merek berkisar mengenai cara menjadi kredibel, menepati janji, dan menciptakan kepercayaan konsumen terhadap merek. Keberadaan identitas yang diperkuat oleh integritas merek akan menghasilkan citra merek (brand image) yang baik di benak pelanggan Kotler et al. (2010).

\section{Pengaruh Model 3i dari Marketing 3.0 terhadap Keputusan Pembelian}

Hills et al. (2008) berpendapat bahwa usaha skala kecil dan menengah memerlukan pendekatan kewirausahaan dalam strategi pemasarannya, yang menurut penelitian terdahulu (Stokes, 2000; Ionita, 2012) berfokus pada penggunaan intuisi informal dalam pengambilan keputusan, karena pemasaran tradisional tidak dapat diterapkan langsung tanpa penyesuaian pada usaha yang belum berskala besar. Inovasi diperlukan untuk dapat menjawab hambatan dan keterbatasan-keterbatasan yang dimiliki oleh pemilik UMKM. Penyesuaian berupa pendekatan yang inovatif untuk memberi nilai tambah pada bisnis diperlukan untuk mengembangkan merek dan meningkatkan kepercayaan pelanggan yang pada gilirannya dapat memengaruhi pengambilan keputusan untuk membeli produk dari merek tersebut. Pendekatan yang digunakan adalah melalui entrepreneurial marketing dengan tujuan mengeksploitasi peluang supaya memperoleh pelanggan melalui pendekatan yang inovatif, salah satu upaya yang dapat dilakukan adalah mengikuti perkembangan era Marketing 3.0 melalui Model 3i.

Menurut Kotler et al. (2010), keputusan konsumen dalam memilih produk pada era Marketing 3.0 dapat dipengaruhi oleh model 3i yang menyusun nilai dari suatu merek. Bagian pertama dalam model 3i adalah identitas merek. Aaker (2015) 
merumuskan bahwa identitas merek yang baik dapat memengaruhi rasa percaya diri pelanggan atas keputusan pembelian. Astuti dan Cahyadi (2007) membuktikan bahwa identitas merek yang baik dapat berpengaruh terhadap keputusan pembelian konsumen. Oleh karena itu, diajukan hipotesis sebagai berikut.

H1: Identitas merek berpengaruh positif terhadap keputusan pembelian.

Bagian kedua dari model 3i adalah integritas merek. Hasil penelitian Pratama et al. (2013) menunjukkan bahwa salah satu hal yang memengaruhi keputusan pembelian adalah kepercayaan merek. Integritas merek merupakan dimensi dari kepercayaan merek, sehingga dirumuskan hipotesis sebagai berikut.

H2: Integritas merek berpengaruh positif terhadap keputusan pembelian.

Bagian ketiga dari model $3 \mathrm{i}$ adalah citra merek, berkaitan dengan kesan yang ditimbulkan di benak konsumen terhadap suatu merek. Saat pengambilan keputusan pembelian konsumen dilakukan, menurut Aaker (2015) kesadaran akan citra merek memegang peran penting. Citra merek memungkinkan preferensi pelanggan dalam memilih suatu merek tertentu. Penelitian terdahulu yang membuktikan bahwa citra merek memberikan pengaruh positif terhadap keputusan pembelian produk misalnya dilakukan oleh Sulistyari dan Yoestini (2012). Berdasarkan uraian teori dan penelitian terdahulu, hipotesis ketiga dirumuskan sebagai berikut.

H3: Citra merek berpengaruh positif terhadap keputusan pembelian.

Berdasarkan rangkaian sejumlah hipotesis sebagaimana yang telah dirumuskan di atas dapat disajikan model penelitian berikut ini.

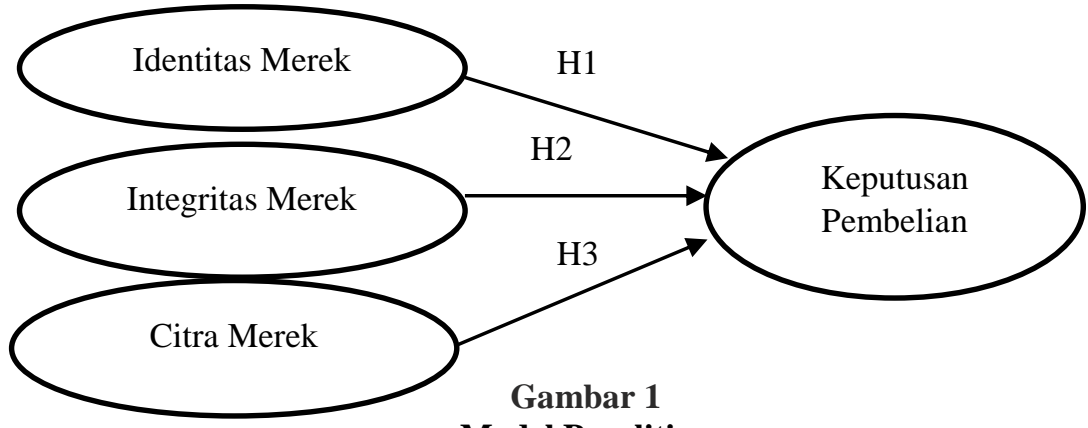

Model Penelitian

\section{METODA PENELITIAN}

Jenis penelitian yang dilakukan adalah penelitian kombinasi (mixed methodology) untuk menghasilkan fakta yang lebih komprehensif dalam meneliti masalah penelitian, karena peneliti memiliki kebebasan untuk menggunakan semua alat pengumpul data sesuai dengan jenis data yang dibutuhkan. Desain penelitian 
kombinasi yang digunakan dalam penelitian ini adalah triangulasi konkuren (concurrent triangulation), dengan mengumpulkan data kuantitatif dan kualitatif dalam satu waktu, kemudian hasilnya diinterpretasi bersama-sama (Creswell 2014).

\section{Penelitian Bagian Pertama: Pendekatan Kualitatif}

Pada bagian pertama, penelitian ini memulai dengan pendekatan kualitatif dengan pengalaman narasumber/ informan yang diekspresikan ke dalam sebuah cerita. Setelah itu, cerita tersebut dipahami maknanya dan dianalisis. Prosedurnya dimulai dengan memfokuskan pada pengkajian terhadap narasumber, pengumpulan data melalui cerita mereka, pelaporan pengalamannya, dan penyusunan kronologis atas makna dari pengalaman tersebut. Penelitian ini mendeskripsikan gambaran informan tentang pemahaman tentang MEA 2015, peran serta Diskoperindag dalam pembinaan UMKM, dan pemahaman tentang Model 3i Marketing 3.0 pada pemasaran bisnisnya.

Pendekatan kualitatif pada penelitian ini melibatkan lima pemilik UMKM di kota Magelang dengan kriteria merupakan UMKM binaan Diskoperindag Kota Magelang yang menitipkan jualannya di Hotel Wisata Magelang, salah satu hotel yang menjadi rekanan Diskoperindag dalam pembinaan UMKM. Data penelitian merupakan data primer yang diperoleh melalui in depth interview terhadap para pemilik UMKM ketika datang ke Hotel Wisata untuk mengecek/ menambah stock barang dagangan. Penelitian ini menggunakan wawancara dengan pertanyaanpertanyaan yang bersifat open-ended, yang menurut Reja, Manfreda, Hlebec, dan Vehovar (2003) adalah pertanyaan yang tidak mudah dijawab dengan respons "ya", "tidak", atau sebuah kata/ frasa singkat. Tujuan dari pertanyaan open-ended adalah untuk mendapatkan jawaban dari informan secara mendalam.

Penelitian ini menggunakan triangulasi sumber data, dengan mengecek data kepada lima informan berbeda dengan aktivitas yang sama, yaitu berbisnis UMKM di bawah binaan Diskoperindag. Deskripsi dilakukan terhadap pertanyaan-pertanyaan terkait masalah penelitian dalam wawancara yang telah diuji keabsahannya: (1) pemahaman para pemilik UMKM tentang MEA, (2) pembinaan yang telah dilakukan Diskoperindag Magelang dalam mendukung perkembangan UMKM, serta (3) pemahaman dan penerapan Model 3i Marketing 3.0 pada UMKM binaan Diskoperindag Magelang.

\section{Penelitian Bagian Kedua: Pendekatan Kuantitatif}

Data kuantitatif diperoleh dari hasil penyebaran kuesioner terhadap para konsumen yang telah melakukan pembelian produk UMKM binaan Diskoperindag Kota Magelang. Pendekatan kuantitatif digunakan dalam penelitian ini untuk melengkapi pemahaman tentang pengaruh model 3i Marketing 3.0.

Teknik sampling yang digunakan dalam penelitan ini adalah convenience sampling, yaitu 40 orang konsumen yang secara kebetulan dijumpai peneliti ketika membeli produk UMKM binaan Diskoperindag Kota Magelang. Instrumen penelitian disusun berdasarkan 3 variabel independen (identitas merek, integritas merek, dan citra 
merek) dengan masing-masing variabel terdiri dari 3 pertanyaan; serta 1 variabel dependen (keputusan pembelian) yang terdiri dari 5 pertanyaan. Semua pengukuran variabel dilakukan oleh para responden dengan menggunakan lima poin skala Likert, mulai dari skor 1 (sangat tidak setuju) hingga skor 5 (sangat setuju).

Data penelitian kuantitatif diuji keabsahannya melalui uji validitas, reliabilitas, dan uji asumsi klasik (normalitas, multikolinearitas, dan heteroskedastisitas). Data yang valid, reliabel, dan memenuhi syarat uji asumsi klasik dianalisis dengan uji regresi linear berganda untuk mengetahui pengaruh variabel-variabel independen terhadap variabel dependen.

\section{HASIL DAN PEMBAHASAN}

\section{Hasil Penelitian}

Data wawancara kepada para informan diidentifikasi dan dianalisis berdasarkan domain yang ditetapkan di awal. Berikut adalah rangkuman jawaban dari kelima informan (Tabel 1 di lampiran). Berdasarkan transformasi hasil wawancara (Tabel 1), diketahui bahwa seluruh informan yang memiliki bisnis UMKM di bawah binaan Diskoperindag Kota Magelang seluruhnya berupa barang kerajinan (batik, lampu hias, dan handycraft). Secara umum, kelima informan menganggap bahwa usahanya berkembang hingga saat ini berkat peran dan dukungan dari Diskoperindag Kota Magelang. Berikut ini pernyataaan Bu Retno Sulistyowati, pemilik Batik Daniswara.

"Sejauh ini kantor dinas banyak bantu kita, Mbak. Sekarang sih usaha saya baru sambilan, tapi lumayan labanya per bulan sekitar 800ribu rupiah lah. Saya yang awalnya cuma tahu beberapa motif batik dan ngga' paham jenis-jenisnya diajarin sama kantor dinas lewat pelatihan-pelatihan, sekarang motif Batik Daniswara lebih beragam."

Informan-informan lainnya menambahkan peran Diskoperindag dalam penyediaan alat dan membantu pemasaran barang dagangannya dengan bekerjasama dengan PHRI Kota Magelang (Persatuan Hotel Rumah Makan seluruh Indonesia). Sistem yang dipakai adalah titip jual, pihak hotel yang dipilih oleh PHRI dan Diskoperindag untuk menjadi rekanan UMKM tersebut tidak mengambil untung dari barang dagangan yang dititipkan. Pernyataan narasumber Bu Supandi, pemilik Batik Boton dipaparkan berikut ini.

"Diskoperindag bantu peralatan kita, Mbak, carikan yang jual alatnya terus bantu ngutang modal ke KUR BRI tanpa jaminan. Karena modal kita masih dikit, bantuan ini sangat bermanfaat,"

Pernyataan lain dari Bu Iwing Sulistiyawati, pemilik Iwing Batik Kebonpolo adalah sebagai berikut.

"Diskoperindag bekerjasama dengan perhotelan di Magelang, jadi toko saya dibantu pemasarannya sehingga boleh nitip jual di Hotel Wisata yang merupakan rekanan 
Diskoperindag. Dari hasil titip di hotel, merek saya jadi lebih dikenal luas terus tamu hotel juga menjadi konsumen dagangan saya."

Strategi pemasaran yang selama ini diterapkan adalah direct selling, membuka galeri/ toko, titip jual ke hotel-hotel rekanan Diskoperindag, dan mengikuti pameran. Kendala yang dihadapi kelima informan yaitu keterbatasan pemasaran dan penggunaan teknologi.

"Pemasaran kita masih terbatas banget, baru merambah ke pasar Magelang dan sekitarnya. Saya susah cari pegawai yang handal yang bisa bantu di pemasaran ke luar kota. Orang-orang nyaranin saya pakai sosial media, tetapi saya ini wong gaptek jadi belum mudheng gimana cara pakai sosial media buat jualan, takut salah,” ungkap $\mathrm{Bu}$ Retno tentang kendala yang dihadapi dalam mengembangkan bisnisnya.

Bapak Arif yang memiliki UMKM di bidang kerajinan lampu hias menambahkan bahwa kendala yang dihadapinya adalah pengalaman pemasaran dan modal usaha:

"Usaha saya saat ini masih kurang berkembang, Mbak. Menurut saya alasannya adalah karena saya ngga' terlalu paham gimana cara pemasaran yang lebih baik. Merek saya belum ada identitasnya, belum punya logo dan sebagainya, hanya sebatas berjalan begitu saja yang penting ngga' rugi. Maklumlah Mbak, modal usaha masih terbatas, ya paling engga' yang bisa saya lakukan ya menjaga mutu dan kualitas dagangan saya aja. Untuk bikin logo, slogan wah belum kepikiran."

Saat ditanya tentang MEA, seluruh informan memahami bahwa MEA dimulai pada akhir tahun 2015, yang merupakan pasar bebas negara-negara ASEAN di mana barang-barang dari negara lain bebas masuk ke Indonesia, sebaliknya pula barangbarang dagangan Indonesia akan bebas masuk ke negara-negara ASEAN. Para informan menyadari bahwa MEA merupakan tantangan bagi mereka karena produkproduk negara lain akan masuk ke Indonesia dan meningkatkan kompetisi. Namun, MEA juga dapat menjadi peluang bagi bisnisnya untuk berkembang lebih baik lagi dan menuntut mereka untuk lebih menghasilkan produk berkualitas sehingga dapat diterima oleh negara lain. Para informan berharap pemerintah akan lebih memberikan dukungan dalam hal pemodalan, pelatihan-pelatihan, dan penyelenggaraan pameran berskala internasional agar bisnis mereka siap untuk menembus pasar luar negeri. Pernyataan berikut adalah dari Ibu Nina R. Maika selaku pemilik Magelang Craft.

"Semoga pemerintah melalui Diskoperindag memberikan dukungan melalui pameran-pameran kerajinan bertaraf internasional sebagai wahana bagi kami para pelaku bisnis UMKM untuk dilirik pasar luar negeri,"

Profil responden dari 40 sampel yang merupakan konsumen UMKM binaan Diskoperindag kota Magelang dapat dilihat pada Tabel 2. 
Tabel 2

Profil Responden

\begin{tabular}{llrr}
\hline \multicolumn{1}{c}{ Kategori } & \multicolumn{1}{c}{ Alternatif Jawaban } & Jumlah (orang) & Persentase \\
\hline Gender & Laki-laki & 8 & $20 \%$ \\
& Perempuan & 32 & $80 \%$ \\
\hline Usia & $\leq 20$ tahun & 0 & $0 \%$ \\
& $21-30$ tahun & 3 & $8 \%$ \\
& $31-40$ tahun & 10 & $25 \%$ \\
& $41-50$ tahun & 25 & $62 \%$ \\
& $>50$ tahun & 2 & $5 \%$ \\
\hline \multirow{2}{*}{ Pekerjaan } & PNS & 15 & $38 \%$ \\
& Karyawan Swasta & 6 & $14 \%$ \\
& Wiraswasta & 11 & $28 \%$ \\
& Pelajar \& Mahasiswa & 4 & $10 \%$ \\
& Lain-lain & 4 & $10 \%$ \\
\hline Jumlah Pembelian & Sekali & 30 & $75 \%$ \\
& Lebih dari Sekali & 10 & $25 \%$ \\
\hline
\end{tabular}

Berdasarkan profil responden tersebut, diketahui bahwa konsumen yang telah membeli produk UMKM binaan sebagian besar adalah perempuan (80\%), dengan usia 41-50 tahun (62\%), pekerjaan mereka sebagian besar adalah PNS (38\%), dan mereka sebagian besar baru sekali membeli produk UMKM tersebut (75\%). Sebelum data kuesioner diolah, diperlukan analisis uji validitas dan reliabilitas terhadap variabelvariabel yang digunakan dalam penelitian. Masing-masing variabel diukur dengan menggunakan sejumlah indikator empirik Hasil analisis validitas dan reliabilitas dari masing-masing variabel tersebut disajikan dalam Tabel 3 (Lampiran).

Berdasarkan Tabel 3 (Lampiran) tampak bahwa pada uji validitas, semua indikator empirik tiap variabel mempunyai nilai corrected item-total correlation atau $r$ hit positif dan $r$ hit $>r_{0,05}(0,2638)$; sehingga indikator empirik dari masing-masing variabel yang diujikan dinyatakan valid. Sementara itu, pada uji reliabilitas yang tak terpisahkan dengan uji validitas, data yang reliabel adalah dengan nilai cronbach Alpha lebih besar dari 0,50 (Sekaran 2010). Dengan demikian, semua variabel memiliki reliabilitas yang tinggi.

Untuk mengetahui pengaruh identitas merek, integritas merek, dan citra merek terhadap keputusan pembelian, maka dilakukan pengujian regresi. Hasil pengujian regresi disajikan pada Tabel 4 .

Tabel 4

Hasil Uji t Model Regresi Berganda

\begin{tabular}{lrrc}
\multicolumn{1}{c}{ Variabel } & Koef B & t hitung & Sig \\
\hline Identitas Merek & 0,820 & $12,499^{*}$ & 0,000 \\
Integritas Merek & 0,167 & $2,673^{*}$ & 0,011 \\
Citra Merek & 0,091 & $1,492^{*}$ & 0,144 \\
\hline
\end{tabular}

Keterangan : $*$ signifikan pada $\alpha=5 \% \quad$ t $0,05(\mathrm{df}=40-3=37)=1,68709$ 
Nilai koefisien determinasi $\left(\mathrm{R}^{2}\right)$ sebesar 0,892 yang berarti bahwa 89,2\% pengaruh keputusan pembelian produk UMKM binaan Diskoperindag dapat dijelaskan secara bersama-sama oleh identitas merek, integritas merek, dan citra merek. Sedangkan sebanyak 10,8\% lainnya dijelaskan oleh variabel lain yang tidak diteliti dalam penelitian ini. Berdasarkan pengujian hipotesis-hipotesis yang diusulkan, disimpulkan bahwa hanya $\mathrm{H} 1$ dan $\mathrm{H} 2$ yang didukung dan dapat dibuktikan, dengan $\mathrm{t}$ hitung $>\mathrm{t}$ tabel $(1,68709)$ dan Sig. $<0,05$. H3 tidak didukung karena $\mathrm{t}$ hitungnya 1,492; lebih kecil dibandingkan t tabel dan Sig. > 0,05. Dapat dikatakan bahwa identitas dan integritas merek berpengaruh positif terhadap keputusan pembelian, sedangkan citra merek tidak memengaruhi keputusan pembelian.

\section{ANALISIS DAN PEMBAHASAN}

Para pemilik UMKM binaan perlu menghasilkan produk berkualitas yang dapat dikenal sehingga dapat diterima oleh pasar negara lain. Produk yang dikenal harus memiliki sebuah identitas merek yang khas. Identitas merek berkisar mengenai positioning merek dalam benak konsumen (Kotler dan Keller 2007). Positioning tersebut haruslah unik agar merek didengar dan diperhatikan oleh pasar, selain juga harus relevan dengan kebutuhan dan keinginan konsumen. Puspito (2013) menyebutkan bahwa strategi pemasaran penting bagi UMKM karena salah satu tujuan utamanya adalah untuk membangun merek. Merek merupakan aset bisnis yang penting untuk memperoleh hati konsumen dan memenangkan persaingan pasar (Kotler dan Keller 2007). Secara umum menurut Puspito (2013), konsumen akan memilih merek produk yang sudah diketahui atau dipercaya sebelumnya, atau dengan kata lain produk yang dipilih adalah yang memiliki integritas merek.

Berdasarkan hasil wawancara dengan para pemilik UMKM binaan, entrepreneurial marketing dari pengembangan merek melalui Model 3i Marketing 3.0 belum optimal. Kelima informan pemilik UMKM hampir seluruhnya telah memahami dan menerapkan identitas merek yang cukup baik di produk mereka. Unsur-unsur identitas merek adalah nama, logo, warna, tagline, dan simbol dari sebuah merek (Kotler dan Armstrong 2003). Hasil analisis regresi menunjukkan bahwa identitas merek memengaruhi keputusan pembelian konsumen.

UMKM binaan Diskoperindag telah memiliki identitas merek yang baik, misalnya pada pemilihan warna dominan yang khas pada Batik Boton, Batik Daniswara dan penggunaan logo kupu-kupu pada Iwing Batik Kebonpolo. Hanya Lampu Hias Arif yang masih belum memiliki identitas merek. Identitas merek oleh Magelang Craft telah lebih matang digarap apabila dibandingkan UMKM lainnya. Identitas merek yang dikembangkan cukup lengkap meliputi penggunaan warna oranye dan pemberian logo Magelang Craft berupa gambar menara air (water toren) yang merupakan ikon kota Magelang. Selain itu, Magelang Craft juga memiliki tagline: "Asli Damelan Tiyang Magelang". Identitas merek perlu beresonansi dengan 
konsumen, berbeda dengan pesaing, dan mewakili apa yang akan dilakukan oleh perusahaan dari waktu ke waktu agar menjadi lebih efektif (D. Aaker \& Joachimsthaler 2000). Hal tersebut telah dilakukan oleh Iwing Batik Kebonpolo yang memberikan filosofi di balik pemilihan logo kupu-kupu, yaitu dari waktu ke waktu ingin memberikan yang lebih baik kepada konsumennya.

Bagian selanjutnya dari segitiga Model 3i adalah integritas merek, yang menurut Kotler dan Keller (2007) adalah tentang bagaimana menjadi kredibel, menepati janji, dan menciptakan kepercayaan konsumen terhadap merek yang dimiliki. Aspek integritas merek UMKM digarap dengan cukup baik oleh pemilik UMKM. Target dari integritas merek menurut Kotler et al. (2010) adalah spirit konsumen. Para informan pemilik UMKM telah mempertahankan integritas, misalnya dengan menjaga mutu dan kualitas produk kerajinan yang diproduksi, menjaga kepribadian khas budaya Indonesia melalui produk yang dikembangkan, serta menggunakan packaging yang baik. Integritas merek berdasarkan uji statistika ternyata memang berpengaruh positif terhadap keputusan pembelian konsumen. Integritas merek penting karena dalam Marketing 3.0 pemasar harus membidik pikiran dan spirit secara simultan untuk meraih hati konsumen (Kotler et al., 2010) . Positioning akan memicu pertimbangan keputusan beli, sebuah merek membutuhkan diferensiasi yang otentik bagi spirit manusia agar mengkonfirmasi keputusan tersebut. Pada gilirannya, hati akan membuat konsumen untuk bertindak dan memutuskan pembelian (Kotler et al., 2010; Kartajaya et al., 2015).

Segitiga Model 3i bagian terakhir adalah brand image (citra merek), yaitu tentang mendapat bagian yang kuat dari emosi konsumen. Aaker (1994) memandang citra merek sebagai serangkaian asosiasi dalam benak konsumen terhadap suatu merek, yang tersusun menjadi suatu makna. Citra merek juga dikatakan oleh Kotler dan Pfoertsch (2008) sebagai penglihatan dan kepercayaan di benak konsumen sebagai cerminan asosiasi yang tertahan di ingatan konsumen. Secara umum, para pemilik UMKM binaan telah mulai memupuk citra merek dalam benak konsumen agar mudah bagi konsumen untuk mengingat UMKM masing-masing. Cara yang diambil masih tergolong sederhana, misalnya dengan penggunaan nama daerah asal (Boton dan Kebonpolo) sebagai atribut identitas mereknya untuk membentuk citra merek produk tersebut berasal dari suatu daerah. Cara lain yang dilakukan UMKM adalah dengan mempertahankan ke-khas-an budaya Indonesia pada kerajinan yang dibuat sehingga melekat di benak konsumen bahwa merek tersebut menjunjung budaya Indonesia. UMKM yang belum memahami konsep dari citra merek adalah Lampu Hias Arif yang belum memberikan identitas tertentu pada mereknya, sehingga citra merek pun tidak terbentuk dengan baik. Hal tersebut sejalan dengan apa yang diungkapkan oleh Kotler et al. (2010) pada model 3i, bahwa bila identitas merek atau integritas merek tidak dijelaskan dan diterapkan dengan baik, maka citra merek yang terbentuk kurang kuat.

Hasil uji hipotesis menunjukkan bahwa citra merek tidak memengaruhi keputusan pembelian. Hasil tersebut bertentangan dengan temuan Musay (2013) yang 
menyebutkan bahwa keputusan pembelian dipengaruhi oleh citra merek yang terdiri atas indikator citra perusahaan, citra pemakai, dan citra produk. Hasil yang tidak sejalan tersebut diduga karena perbedaan ukuran unit bisnis. Penelitian Musay (2013) tersebut dilakukan pada restoran cepat saji yang memang telah memiliki citra merek yang kuat, terbukti dengan menjadi Top Brand Award tahun 2011 dan 2012. Ukuran unit bisnis pada penelitian ini adalah UMKM yang berdasarkan hasil wawancara dengan para pemiliknya belum menunjukkan adanya citra merek yang kuat.

Penyebab lain dari tidak adanya pengaruh citra merek terhadap keputusan pembelian diduga karena rata-rata konsumen yang menjadi sampel pada penelitian ini adalah lebih banyaknya konsumen yang baru sekali membeli (75\%), sehingga bagi mereka citra merek tidaklah penting. Hal yang lebih dianggap penting sebagai bahan pertimbangan dalam keputusan membeli produk UMKM bagi mereka adalah ciri khas produk (dalam hal ini produk khas Magelang) yang diterjemahkan identitas merek (misal melalui tagline tertentu). Pertimbangan lainnya adalah kualitas dan mutu produk yang merupakan bagian dari integritas merek. Citra merek berdasarkan wawancara dengan para pemilik UMKM belum terbentuk secara kuat, sehingga ketika data kuesioner diuji hasilnya tidak memengaruhi keputusan pembelian.

Meilani dan Simanjuntak (2012) mengemukakan bahwa faktor yang memengaruhi keputusan beli konsumen terhadap produk skala UMKM secara simultan adalah kualitas produk, layanan yang dirasakan dan harga. Tiningrum (2014) secara lebih spesifik menyebutkan bahwa keputusan pembelian produk kerajinan batik skala UMKM adalah dipengaruhi oleh bauran pemasarannya (4P). Pada bisnis skala UMKM citra merek menjadi kurang bermakna karena konsumen hanya cenderung memperhatikan identitas merek melalui informasi produk khas dari daerah tertentu dengan nama merek dan tagline tertentu yang menarik (misalnya pada Magelang Craft: "Asli Damelan Tiyang Magelang"). Hal lain yang diperhatikan adalah kualitas dan mutu produk sebagai bagian dari integritas merek. Citra merek pada UMKM binaan belum mampu memengaruhi keputusan pembelian produk oleh konsumen, walaupun citra merek tersebut sudah mulai direncanakan untuk dikembangkan oleh pemiliknya.

Penelitian ini memberikan gambaran tentang penerapan dari entrepreneurial marketing dalam era Marketing 3.0 melalui pengembangan Model 3i. Berdasarkan hasil wawancara, tampak bahwa secara umum pemilik UMKM binaan telah memahami pentingnya membangun merek melalui pengembangan identitas, integritas, dan citra merek. Hanya saja cara yang digunakan masih cukup sederhana dengan memberi nama, logo, tagline untuk identitas merek; menjaga mutu dan kualitas untuk mempertahankan integritas merek; serta membangun citra merek melalui identitas merek yang dipilih dan memperkuatnya dengan integritas merek.

Pemerintah sebenarnya telah melakukan pemetaan terhadap potensi ekspor produk UMKM ke ASEAN dan negara lain, serta memfasilitasi promosi produk 
UMKM (Majalah Swa Online, 2014). Tugas bagi pelaku UMKM adalah bagaimana mereka melakukan branding yang baik sesuai dengan era Marketing 3.0, yaitu dengan memperkuat model 3i. Identitas merek adalah seperangkat asosiasi merek yang unik yang diciptakan oleh para penyusun strategi merek (Kotler \& Keller 2007). Identitas merek akan membantu kemantapan hubungan antara merek dan pelanggan melalui proposisi nilai (value proposition) (Kotler \& Keller 2007). Cara memberikan identitas merek UMKM misalnya melalui ciri-ciri khusus untuk menggambarkan asal daerah tempat produksi dari produk tersebut. Identitas merek juga sebaiknya dikembangkan melalui e-commerce seperti membuat website yang berisi produk yang dijual dan juga informasi seputar produknya. Bagian kedua dari model $3 \mathrm{i}$ adalah integritas merek dapat dilakukan dengan meningkatkan kualitas dan mutu, serta memberikan pelayanan penjualan yang baik. Harapan dari dipupuknya integritas merek sebagai penguat dari identitas merek adalah agar citra dari produk-produk UMKM semakin unggul sehingga dapat bersaing di pasar global yang borderless karena adanya MEA. Daya saing yang tinggi pada gilirannya akan meningkatkan keputusan pelanggan dalam membeli produk UMKM.

Strategi entrepreneurial marketing menurut Morrish et al. (2010) dikembangkan dari suatu gagasan dan pola pikir untuk tindakan yang digerakkan oleh peluang. Hasil penelitian menunjukkan bahwa strategi yang dapat dikembangkan adalah pembinaan pemerintah terhadap UMKM melalui pelatihan pemasaran tentang ekuitas merek, terutama pada era Marketing 3.0 berdasarkan pengembangan model $3 \mathrm{i}$. Pemahaman yang mendalam tentang identitas, integritas, dan citra merek harus diberikan pada pemilik UMKM; bukan hanya sebatas pelatihan-pelatihan ketrampilan. Era Marketing 3.0 merupakan masa di mana pebisnis harus melakukan pendekatan holistik pada pelanggan dengan melihatnya sebagai manusia multidimensi yang didorong oleh nilai-nilai tertentu dan merupakan mitra kolaborasi (Kotler et al., 2010). Sementara itu, Kartajaya et al. (2015) menambahkan bahwa di era Marketing 3.0 perusahaan harus mengkomunikasikan nilainya, memposisikan merek yang dimiliki sebagai kekuatan positif, sehingga sukses berkolaborasi dengan para pelanggannya. UMKM harus dapat meningkatkan reputasinya dengan membangun merek yang lebih baik dan mengkomunikasikannya kepada pelanggan.

Perkembangan Marketing 3.0 didukung oleh teknologi digital yang menandai era connectivity antara perusahaan dengan pelanggannya (Kartajaya et al., 2015). Revolusi digital tersebut menyebabkan perusahaan semakin mudah dijangkau konsumennya melalui internet dari mana saja. Strategi yang dapat dilakukan pemerintah agar UMKM dapat berkompetisi dalam era teknologi digital adalah melatih para pemilik UMKM menggunakan web dan SEO (Search Engine Optimization), serta atribut pendukung e-commerce lainnya. Bila UMKM dapat mengoptimalkan perkembangan atribut digital tersebut, mereka akan menjangkau pasar yang lebih luas dan memperkenalkan mereknya secara lebih luas lewat website dan media sosial. 
Pembinaan lain yang harusnya dikembangkan pemerintah adalah pelatihan bahasa asing, sehingga UMKM dapat mengkomunikasikan produk dan mereknya dalam bahasa asing yang lebih mengena di hati konsumen dari pasar global. Hal tersebut sejalan dengan yang diungkapkan Aaker (2015), bahwa fungsi pemberian atribut merek dalam bahasa asing adalah untuk membantu menyampaikan informasi produk kepada konsumen agar konsumen merasa produk yang ditawarkan lebih kredibel, sehingga pada gilirannya dapat memengaruhi keputusan konsumen dalam membeli produk tersebut.

\section{SIMPULAN, KETERBATASAN DAN IMPLIKASI}

\section{Simpulan}

Penelitian terhadap Model 3i Marketing 3.0 pada UMKM ini dilakukan dengan metode kombinasi desain triangulasi konkuren yang terdiri dari dua bagian penelitian. Bagian pertama menunjukkan gambaran tentang peranan pemerintah melalui Diskoperindag dalam membina UMKM untuk menyambut MEA 2015, antara lain dalam penyediaan peralatan, pelatihan-pelatihan tentang ketrampilan yang ditekuni, dan pengembangan pemasaran. Hasil wawancara menunjukkan bahwa para pemilik UMKM telah memahami MEA bukan hanya merupakan tantangan, tetapi juga menjadi peluang untuk berkembang. Para pemilik UMKM berharap agar pemerintah membina pengembangan produk dan pemasarannya agar mereka siap menyambut MEA. Bagian kedua menunjukkan bahwa 89,2\% pengaruh keputusan pembelian produk UMKM binaan Diskoperindag dapat dijelaskan secara bersama-sama oleh bagian-bagian dari Model 3i. Namun, secara parsial hanya identitas merek dan integritas merek saja yang memengaruhi keputusan pembelian produk, sedangkan citra merek tidak memengaruhi keputusan pembelian produk. Harapannya, pemerintah dapat membantu UMKM memperdalam entrepreneurial strategy Marketing 3.0 Model 3i (identitas merek, integritas merek, dan citra merek) agar UMKM turut mendukung perekonomian Indonesia di era MEA.

\section{Keterbatasan dan Saran}

Analisis data pada bagian kedua penelitian tidak dipisahkan antara konsumen yang baru sekali melakukan pembelian dengan yang telah lebih dari sekali melakukan pembelian, sehingga tidak dapat dibandingkan bagaimana perbedaan pengaruh model 3i terhadap keputusan pembelian pada dua jenis konsumen tersebut. Untuk penelitian selanjutnya agar mempertimbangkan perbedaan tersebut dengan memilah antara konsumen yang sekali membeli dengan yang telah lebih dari sekali. Penelitian ini berfokus hanya pada Model 3i yang masih mengesampingkan aspek-aspek lain dari Marketing 3.0 yang kemungkinan juga memengaruhi keputusan pembelian konsumen. Penelitian selanjutnya bisa ditambahkan aspek nilai perusahaan dalam Marketing 3.0 yang oleh Kotler et al. (2010) diterjemahkan melalui shared values dan common behavior perusahaan. Saran bagi pemerintah adalah membantu pengembangan merek UMKM berdasarkan 3i serta membantu pengurusan perijinan dan hak paten, sehingga 
produk UMKM semakin kredibel dan memperoleh atensi dari pasar global.

\section{Implikasi}

Implikasi dari temuan penelitian desain triangulas konkuren ini mencakup dua hal, yaitu implikasi teoretis dan praktis. Implikasi teoretis berhubungan dengan kontribusi penelitian bagi perkembangan teori-teori pemasaran, khususnya model $3 \mathrm{i}$ dalam era Marketing 3.0. Implikasi praktis berkaitan dengan kontribusi temuan penelitian terhadap persiapan UMKM dalam MEA.

Hasil penelitian ini menunjukkan bahwa UMKM belum menerapkan strategi merek yang baik sesuai era Marketing 3.0, didukung oleh tidak adanya pengaruh citra merek terhadap keputusan pembelian konsumen. Oleh karena itu, masih perlu dikembangkan pemasaran yang tepat bagi UMKM untuk menyambut MEA sehubungan dengan perkembangan mereknya. Gambaran model 3i dapat menjadi panduan dalam menyusun teori yang sesuai. Proposed framework berdasarkan analisis penelitian adalah segitiga 3i yang dapat dikatakan sebagai segitiga sama kaki dengan dua bagian dari segitiga 3i yang memengaruhi keputusan pembelian produk UMKM, yaitu identitas dan integritas merek. Penelitian ini belum mampu menunjukkan pengaruh citra merek yang positif dan signifikan terhadap keputusan pembelian produk.

Secara praktis, dari penelitian ini tampak bahwa pembinaan pemerintah kepada UMKM perlu ditambah tentang pemahaman Marketing 3.0. UMKM dapat mengadopsi model $3 \mathrm{i}$ dalam mengembangkan mereknya setelah memperoleh pembinaan, sehingga kian mahir memberikan identitas merek, mengkomunikasikannya dalam nama, logo, tagline baik secara langsung maupun melalui website dan media sosial. UMKM juga diharapkan semakin meningkatkan integritas mereknya dengan menjaga reputasi, mutu dan kualitas produk yang ditawarkan, serta keunggulan-keunggulan lainnya seperti pelayanan yang baik, untuk meningkatkan kepercayaan pelanggan terhadap produk. Identitas merek yang diperkuat dengan integritas merek akan menciptakan citra merek yang kuat untuk memengaruhi keputusan pembelian konsumen. Harapannya, UMKM akan siap menyambut MEA karena memperoleh atensi dari pasar global.

\section{DAFTAR PUSTAKA}

Aaker, David. 2015. Aaker on branding. Jakarta: PT Gramedia Pustaka Utama.

Aaker, David A. 1994. "Building a brand: the saturn story." California Management Review 36 (2): 104-13. https://doi.org/10.2307/41165748.

Aaker, David, dan Erich Joachimsthaler. 2000. Brand leadership. Journal of Marketing. New York: The Free Press. https://doi.org/10.2307/1252048.

Anggarani, Ari, Winadi Prasetyoning Tyas, dan Vita Intan Safitri. 2014. "Penguatan Sektor Umkm Sebagai Strategi Menghadapi Mea 2015.” Jurnal Ekonomi 5 (1): $42-48$. 
Astuti, Sri Wahyuni, dan I Gede Cahyadi. 2007. "Pengaruh elemen ekuitas merek terhadap rasa percaya diri pelanggan di Surabaya atas keputusan pembelian sepeda motor Honda." Majalah ekonomi 18 (2): 145-56. https://doi.org/10.20473/JEBA.V17I22007.4207.

Becherer, R. C., P. J. Haynes, dan L. P. Fletcher. 2006. "Paths to profitability in owneroperated firms: the role of entrepreneurial." Journal of Business and Entrepreneurship 18 (1): 17-31.

Creswell, Jw. 2014. Research Design : Pendekatan Kualitatif, Kuantitatif, dan MIxed. Research design. Yogyakarta: Pustaka Pelajar. https://doi.org/10.2307/3152153.

Ganie, Yassa Ardhi. 2012. "Kiprah BI Menyongsong MEA 2015.” Newsletter Bank Indonesia, 2012.

Hadiyati, Ernani. 2015. "Marketing and government policy on msmes in indonesian: a theoretical framework and empirical study." International Journal of Business and Management $10 \quad$ (2): $128-41$. https://doi.org/10.5539/ijbm.v10n2p128.

Hills, Gerald E., Claes M. Hultman, dan Morgan P. Miles. 2008. "The evolution and development of entrepreneurial marketing." Journal of Small Business Management $46 \quad$ (1): 99-112. https://doi.org/10.1111/j.1540627X.2007.00234.x.

Ionita, David. 2012. "Entrepreneurial marketing: a new approach for challenging times." Management \& Marketing: Challenges for the Knowledge Society 7 (1): 131-50. https://doi.org/10.5295/cdg.100190jg.

Kartajaya, Hermawan, dan 25 MarkPlus-ers. 2015. Indonesia wow, markplus wow, we are wow. Indonesia: Gramedia Pustaka Utama.

Kotler, Philip, dan Gary Armstrong. 2003. Dasar-dasar pemasaran. Jakarta: Erlangga.

Kotler, Philip, dan Kevin Lane Keller. 2007. Manajemen Pemasaran. Edisi 12. Jakarta: PT Indeks.

Kotler, Philip, dan Waldemar Pfoertsch. 2010. B2B brand management. B2B Brand Management. Jakarta: PT Bhuana Ilmu Populer. https://doi.org/10.1007/9783-540-44729-0.

Morris, Michael H., Minet Schindehutte, dan Raymond W. LaForge. 2002. "Entrepreneurial Marketing: A Construct for Integrating Emerging Entrepreneurship and Marketing Perspectives." Journal of Marketing Theory and Practice 10 (4): 1-19. https://doi.org/10.1080/10696679.2002.11501922.

Morrish, Sussie C., Morgan P. Miles, dan Jonathan H. Deacon. 2010. "Entrepreneurial marketing: Acknowledging the entrepreneur and customer-centric 
interrelationship." Journal of Strategic Marketing 18 (4): 303-16. https://doi.org/10.1080/09652541003768087.

Musay, Fransisca Paramitasari. 2013. "Pengaruh brand image terhadap keputusan pembelian (survei pada konsumen KFC Kawi Malang)." Jurnal Administrasi Bisnis 3 (2).

Pandeya, Tarun. 2010. "Entrepreneurial Marketing: Prospects and Challenges." BVI R Management Edge 4 (1): 57-65.

Peter, J. Paul, dan Jerry C. Olson. 2000. Consumer behavior: perilaku konsumen dan strategi pemasaran. jilid 2. edisi 4. Jakarta: Erlangga.

Pratama, Dhio Panji, dan Sri Suryoko. 2013. "Pengaruh Threat Emotions, Kepercayaan Merek Dan Harga." Journal of Social and Politic 1 (1): 1-10.

Puspito, Hermas. 2013. "Mengapa strategi marketing penting untuk ukm." Youth Marketers \#16, 2013.

Reja, Urša, Katja Lozar Manfreda, Valentina Hlebec, dan Vasja Vehovar. 2003. "Open-ended vs. close-ended questions in web questionnaires." Developments in Applied Statistics 19 (1): 161-77.

Setiadi, Nugroho J. 2003. Perilaku Konsumen. Kencana. Jakarta. Jakarta: Prenada Media Jakarta. https://doi.org/10.22146/jh.v12i1.1294.

Stokes, David, dan David Stokes. 2000. "Entrepreneurial marketing; a conceptualization from qualitative research." Qualitative Market Research 3 (1): 47-54. https://doi.org/10.1108/13522750010310497.

Sulistyari, Ikanita Novirina, dan Yoestini. 2012. "Analisis pengaruh citra merek, kualitas produk, dan harga terhadap minat beli produk oriflame." Diponegoro Journal of Management 1 (1): 1-17.

Swastha, Basu, dan Irawan. 2008. Manajemen pemasaran modern. cetakan ketujuh. Yogyakarta: Liberty.

Tambunan, Tulus T H. 2012. Pasar bebas ASEAN: peluang, tantangan dan ancaman bagi UMKM Indonesia. Jakarta: Kementrian Koperasi UMKM.

“Tantangan dan peluang UKM jelang MEA 2015.” 2014. Majalah SWA Online. 2014.

Tiningrum, Erna. 2014. "Pengaruh bauran pemasaran terhadap keputusan pembelian batik di usaha kecil menengah batik surakarta." Advance 1 (2): 63-79.

Yohana F. Cahya Palupi Meilani, dan Sahat Simanjuntak. 2012. "Faktor yang mempengaruhi minat beli produk makanan dan minuman usaha kecil menengah kabupaten tangerang." Jurnal Manajemen dan Kewirausahaan 14 (2): 164-71. 


\section{LAMPIRAN}

Tabel 3

Hasil Uji Validitas dan Reliabilitas

\begin{tabular}{|c|c|c|c|}
\hline Variabel & Indikator Empirik & $\begin{array}{l}\text { Corrected item- } \\
\text { total correlation }\end{array}$ & $\begin{array}{l}\text { Cronbach } \\
\text { Alpha }\end{array}$ \\
\hline \multirow{3}{*}{$\begin{array}{l}\text { Identitas } \\
\text { Merek }\end{array}$} & UMKM mencantumkan nama merek pada kemasan & 0,681 & \multirow{3}{*}{0,837} \\
\hline & $\begin{array}{l}\text { Produk UMKM memiliki ciri khas tertentu yang membedakannya } \\
\text { dengan merek yang lain }\end{array}$ & 0,804 & \\
\hline & UMKM memiliki logo perusahaan & 0,623 & \\
\hline \multirow{3}{*}{$\begin{array}{l}\text { Integritas } \\
\text { Merek }\end{array}$} & Produk UMKM ini memiliki kualitas yang baik & 0,739 & \multirow{3}{*}{0,890} \\
\hline & Produk UMKM dikemas dengan baik & 0,889 & \\
\hline & Anda memiliki kepercayaan terhadap merek produk UMKM ini & 0,740 & \\
\hline \multirow{3}{*}{$\begin{array}{l}\text { Citra } \\
\text { Merek }\end{array}$} & $\begin{array}{l}\text { Citra Korporat: Anda pernah mendengar nama UMKM ini } \\
\text { sebelumnya. }\end{array}$ & 0,604 & \multirow{3}{*}{0,779} \\
\hline & $\begin{array}{l}\text { Citra Produk: Anda membeli produk UMKM karena kualitasnya } \\
\text { yang baik sesuai dengan harganya }\end{array}$ & 0,891 & \\
\hline & $\begin{array}{l}\text { Citra Pemakai: Anda akan merasa bangga ketika menggunakan } \\
\text { produk UMKM }\end{array}$ & 0,418 & \\
\hline \multirow{5}{*}{$\begin{array}{l}\text { Keputusan } \\
\text { Pembelian }\end{array}$} & Produk yang Anda beli ini memenuhi kebutuhan Anda & 0,641 & \multirow{5}{*}{0,880} \\
\hline & $\begin{array}{l}\text { Sebelum membeli, Anda melakukan pertimbangan dengan cara } \\
\text { mengumpulkan informasi dari orang lain }\end{array}$ & 0,748 & \\
\hline & $\begin{array}{l}\text { Anda melakukan perbandingan dengan merek lain sebelum } \\
\text { memutuskan membeli produk ini }\end{array}$ & 0,701 & \\
\hline & Anda membeli produk ini melalui pertimbangan yang masak & 0,704 & \\
\hline & $\begin{array}{l}\text { Anda puas dengan keputusan yang Anda ambil untuk membeli } \\
\text { produk ini }\end{array}$ & 0,783 & \\
\hline
\end{tabular}

Tabel 5

Rangkuman Hasil Wawancara terhadap Lima UMKM Binaan Diskoperindag

Masalah Penelitian \#1

Pemahaman para pemilik UMKM tentang MEA

\begin{tabular}{|c|c|c|c|c|c|}
\hline \multirow{2}{*}{ Pertanyaan } & \multicolumn{5}{|c|}{ Ringkasan Tabel Responden } \\
\hline & Responden A & Responden B & Responden C & Responden D & Responden E \\
\hline $\begin{array}{l}\text { Pemahaman } \\
\text { tentang MEA }\end{array}$ & $\begin{array}{l}\text { MEA } \\
\text { menyebabkan } \\
\text { barang-barang } \\
\text { dari luar } \\
\text { negeri bebas } \\
\text { masuk ke } \\
\text { Indonesia }\end{array}$ & $\begin{array}{l}\text { MEA dimulai } \\
\text { pada akhir } \\
\text { tahun } 2015, \\
\text { merupakan } \\
\text { perdagangan } \\
\text { bebas antar } \\
\text { negara di } \\
\text { ASEAN }\end{array}$ & $\begin{array}{l}\text { MEA } \\
\text { menyebabkan } \\
\text { barang-barang } \\
\text { dari negara lain } \\
\text { bebas masuk ke } \\
\text { Indonesia, } \\
\text { sehingga } \\
\text { meningkatkan } \\
\text { persaingan }\end{array}$ & $\begin{array}{l}\text { Pasar bebas } \\
\text { negara } \\
\text { ASEAN, } \\
\text { barang bebas } \\
\text { keluar masuk. }\end{array}$ & $\begin{array}{l}\text { Perdagangan } \\
\text { terbuka di } \\
\text { ASEAN, } \\
\text { masuknya } \\
\text { barang-barang } \\
\text { impor tanpa } \\
\text { pajak. }\end{array}$ \\
\hline $\begin{array}{l}\text { MEA sebagai } \\
\text { tantangan/ } \\
\text { peluang }\end{array}$ & $\begin{array}{l}\text { Tantangan: } \\
\text { harus selalu } \\
\text { memperbaiki } \\
\text { produk yang } \\
\text { dijual, } \\
\text { Peluang: dapat } \\
\text { merambah ke } \\
\text { pasar global }\end{array}$ & $\begin{array}{l}\text { Tantangan: } \\
\text { harus lebih } \\
\text { berkreasi; } \\
\text { Peluang: dapat } \\
\text { mengembang- } \\
\text { kan pasar } \\
\text { untuk } \\
\text { memajukan } \\
\text { usaha }\end{array}$ & $\begin{array}{l}\text { Tantangan: } \\
\text { untuk lebih } \\
\text { meningkatkan } \\
\text { kualitas produk } \\
\text { agar tidak kalah } \\
\text { saing Peluang: } \\
\text { produk dapat } \\
\text { masuk ke } \\
\text { negara lain. }\end{array}$ & $\begin{array}{l}\text { Merupakan } \\
\text { peluang untuk } \\
\text { memasarkan } \\
\text { produk ke } \\
\text { negara lain } \\
\text { dengan ciri } \\
\text { khas produk } \\
\text { indonesia }\end{array}$ & $\begin{array}{l}\text { MEA } \\
\text { merupakan } \\
\text { tantangan bagi } \\
\text { produk lokal } \\
\text { pada segi } \\
\text { harga } \\
\text { walaupun } \\
\text { kualitas jauh } \\
\text { lebih baik. }\end{array}$ \\
\hline
\end{tabular}




\begin{tabular}{llllll}
\hline Harapan terhadap & Pemerintah & Produk akan & Pemerintah & Pemerintah & Adanya \\
usaha bisnis dari & membantu & lebih & dapat membantu & membantu & dukungan dari \\
diselenggarakanny & UMKM & disenangi oleh & UMKM untuk & dalam hal & pemerintah \\
a MEA & mengembang- & negara-negara & pemasaran ke & modal, & untuk pameran \\
& kan produknya & ASEAN & luar negeri & pelatihan dan & kerajinan \\
& agar bisa & sehingga & & pemasaran ke & bertaraf \\
& dijual di & meningkatkan & & negara lain & internasional. \\
& negara lain. & penjualan & & & \\
\hline
\end{tabular}

Masalah Penelitian \#2
Pembinaan Diskoperindag dalam Mendukung Perkembangan UMKM untuk Menyambut MEA 2015

\begin{tabular}{|c|c|c|c|c|c|c|c|}
\hline \multirow{2}{*}{ Pertanyaan } & \multicolumn{7}{|c|}{ Ringkasan Tabel Responden } \\
\hline & Responden A & Responden B & Responden C & \multicolumn{2}{|c|}{ Responden D } & \multicolumn{2}{|c|}{ Responden E } \\
\hline $\begin{array}{l}\text { Strategi pemasaran } \\
\text { yang telah } \\
\text { diterapkan }\end{array}$ & $\begin{array}{l}\text { - } \text { Galeri } \\
\text { (toko) } \\
\text { - Direct } \\
\text { selling } \\
\text { - Pameran }\end{array}$ & $\begin{array}{l}\text { - Titip barang } \\
\text { di Hotel } \\
\text { Wisata } \\
\text { Magelang } \\
\text { - Pameran }\end{array}$ & 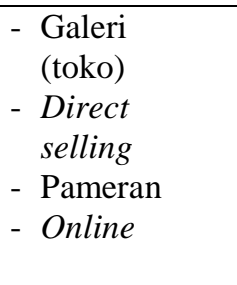 & \multicolumn{2}{|c|}{$\begin{array}{l}\text { - } \text { Titip jual ke } \\
\text { hotel-hotel } \\
\text { - Pameran } \\
\text { - Getok tular }\end{array}$} & \multicolumn{2}{|c|}{$\begin{array}{l}\text { - Titip jual di } \\
\text { outlet, hotel, } \\
\text { dan toko oleh- } \\
\text { oleh } \\
\text { - Secara online } \\
\text { melalui } \\
\text { website }\end{array}$} \\
\hline $\begin{array}{l}\text { Perkembangan } \\
\text { usaha saat ini }\end{array}$ & $\begin{array}{l}\text { Usaha } \\
\text { berkembang } \\
\text { cukup baik }\end{array}$ & $\begin{array}{l}\text { Usaha } \\
\text { berkembang } \\
\text { cukup baik }\end{array}$ & $\begin{array}{l}\text { Semakin maju } \\
\text { dengan } \\
\text { dukungan } \\
\text { Diskoperindag }\end{array}$ & \multicolumn{2}{|c|}{$\begin{array}{l}\text { Masih kurang } \\
\text { berkembang }\end{array}$} & \multicolumn{2}{|c|}{$\begin{array}{l}\text { Omset } \\
\text { meningkat }\end{array}$} \\
\hline $\begin{array}{l}\text { Kendala usaha } \\
\text { yang dihadapi }\end{array}$ & $\begin{array}{l}\text { Keterbatasan } \\
\text { pemasaran }\end{array}$ & $\begin{array}{l}\text { - Keterbatasan } \\
\text { Pemasaran } \\
\text { - Pemilik } \\
\text { gaptek }\end{array}$ & $\begin{array}{l}\text { Pemasaran } \\
\text { belum sampai } \\
\text { ke luar pulau }\end{array}$ & \multirow{2}{*}{\multicolumn{2}{|c|}{$\begin{array}{l}\text { - Kurang } \\
\text { pengalaman } \\
\text { pemasaran } \\
\text { - Kurang } \\
\text { modal usaha } \\
\text { - Memberikan } \\
\text { penyuluhan } \\
\text { - Membantu } \\
\text { pemasaran } \\
\text { dengan titip } \\
\text { jual ke hotel } \\
\end{array}$}} & \multicolumn{2}{|c|}{$\begin{array}{l}\text { Bahan baku yang } \\
\text { terbatas }\end{array}$} \\
\hline $\begin{array}{l}\text { Peran } \\
\text { Diskoperindag } \\
\text { Magelang }\end{array}$ & $\begin{array}{l}\text { Membantu } \\
\text { penyediaan } \\
\text { peralatan dan } \\
\text { mengembang- } \\
\text { kan } \\
\text { pemasaran } \\
\end{array}$ & $\begin{array}{l}\text { Sangat } \\
\text { membantu } \\
\text { untuk pameran } \\
\text { dan pelatihan } \\
\text { tentang } \\
\text { kerajinan batik } \\
\end{array}$ & $\begin{array}{l}\text { Membantu } \\
\text { peralatan dan } \\
\text { pemasaran (ke } \\
\text { Hotel Wisata } \\
\text { untuk dapat } \\
\text { titip display) }\end{array}$ & & & \multicolumn{2}{|c|}{$\begin{array}{l}\text { Memberikan } \\
\text { pelatihan }\end{array}$} \\
\hline \multicolumn{8}{|c|}{$\begin{array}{c}\text { Masalah Penelitian \#3 } \\
\text { Pemahaman dan Penerapan Model 3i Marketing 3.0 pada UMKM Binaan Diskoperindag } \\
\text { Magelang }\end{array}$} \\
\hline \multirow{2}{*}{ Pertanyaan } & \multicolumn{7}{|c|}{ Ringkasan Tabel Responden } \\
\hline & Responden A & Responden B & Responden & & Respon & n D & Responden E \\
\hline $\begin{array}{l}\text { Pemahaman dan } \\
\text { penerapan } \\
\text { identitas merek }\end{array}$ & $\begin{array}{l}\text { Pemilihan } \\
\text { warna yang } \\
\text { khas pada tiap } \\
\text { produknya }\end{array}$ & $\begin{array}{l}\text { Pemilihan } \\
\text { warna } \\
\text { dominan yang } \\
\text { membedakan } \\
\text { tiap kain yang } \\
\text { dibuat }\end{array}$ & $\begin{array}{l}\text { Identitas merek } \\
\text { dengan logo kup } \\
\text { kupu, meng- } \\
\text { gambarkan sebu } \\
\text { proses transform } \\
\text { dari ulat menjad } \\
\text { kupu-kupu canti } \\
\text { Harapannya, Iwi } \\
\text { Batik bertransfo } \\
\text { menjadi lebih ba } \\
\text { lagi. }\end{array}$ & $\begin{array}{l}\text { d- } \\
\text { asi } \\
\text { masi } \\
\text { m } \\
\text { ma }\end{array}$ & $\begin{array}{l}\text { Belum } \\
\text { memiliki } \\
\text { identitas } \\
\text { merek ya } \\
\text { jelas }\end{array}$ & & $\begin{array}{l}\text { Penggunaan } \\
\text { warna, logo, } \\
\text { dan tagline } \\
\text { (“Asli } \\
\text { Damelan } \\
\text { Tiyang } \\
\text { Magelang” - } \\
\text { Asli Buatan } \\
\text { Orang } \\
\text { Magelang) }\end{array}$ \\
\hline
\end{tabular}




\begin{tabular}{|c|c|c|c|c|c|}
\hline $\begin{array}{lr}\text { Pemahaman } & \text { dan } \\
\text { penerapan } & \text { citra } \\
\text { merek } & \end{array}$ & $\begin{array}{l}\text { Penggunaan } \\
\text { nama daerah } \\
\text { asal yang akan } \\
\text { mudah diingat } \\
\text { pelanggan }\end{array}$ & $\begin{array}{l}\text { Kain batik } \\
\text { Daniswara } \\
\text { dikenal } \\
\text { nyaman } \\
\text { dipakai dan } \\
\text { memiliki nilai } \\
\text { khas busana } \\
\text { Indonesia }\end{array}$ & $\begin{array}{l}\text { Penggunaan nama } \\
\text { pemilik dan lokasi } \\
\text { usaha agar konsumen } \\
\text { mudah mengingat. }\end{array}$ & $\begin{array}{l}\text { Belum } \\
\text { memiliki citra } \\
\text { merek }\end{array}$ & $\begin{array}{l}\text { Citra merek } \\
\text { dijaga dengan } \\
\text { kemasan yang } \\
\text { rapi, } \\
\text { pelayanan } \\
\text { yang cepat, } \\
\text { kualitas baik. }\end{array}$ \\
\hline $\begin{array}{l}\text { Pemahaman dan } \\
\text { penerapan } \\
\text { integritas merek }\end{array}$ & $\begin{array}{l}\text { Tetap menjaga } \\
\text { mutu dan } \\
\text { kualitas kain } \\
\text { batik yang } \\
\text { dijual }\end{array}$ & $\begin{array}{l}\text { Batik sebagai } \\
\text { busana khas } \\
\text { Indonesia } \\
\text { harus menjaga } \\
\text { budaya khas } \\
\text { Indonesia }\end{array}$ & $\begin{array}{l}\text { Integritas merek } \\
\text { dijaga dengan } \\
\text { mempertahan-kan } \\
\text { kualitas kain batik. }\end{array}$ & $\begin{array}{l}\text { Menjaga } \\
\text { kualitas } \\
\text { barang }\end{array}$ & $\begin{array}{l}\text { Menjaga } \\
\text { kualitas } \\
\text { barang dan } \\
\text { kemasan yang } \\
\text { baik. }\end{array}$ \\
\hline $\begin{array}{l}\text { Upaya } \\
\text { pengembangan } \\
\text { merek dagang }\end{array}$ & $\begin{array}{l}\text { Ada nama } \\
\text { merek dan logo }\end{array}$ & $\begin{array}{l}\text { Hanya ada } \\
\text { nama merek }\end{array}$ & $\begin{array}{l}\text { Sedang mengurus hak } \\
\text { paten merek dagang } \\
\text { di Kemenhum dan } \\
\text { HAM }\end{array}$ & $\begin{array}{l}\text { Sedang } \\
\text { mengurus } \\
\text { nama dagang } \\
\text { dan hak paten }\end{array}$ & $\begin{array}{l}\text { Membuat logo } \\
\text { dan tagline }\end{array}$ \\
\hline
\end{tabular}

Keterangan Responden: $\mathrm{A}=$ Batik Boton; $\mathrm{B}=\mathrm{Batik}$ Daniswara; $\mathrm{C}=\mathrm{Iwing}$ Batik Kebonpolo; $\mathrm{D}=$ Lampu Hias Arif; E=Magelang Craft 
